\title{
Models and mechanisms of exercise-induced asthma
}

\begin{abstract}
A.N. Freed
Models and mechanisms of exercise-induced asthma. A.N. Freed. CERS Journals Ltd 1995.

ABSTRACT: Airflow-induced bronchoconstriction (AIB) in mammals can be broadly categorized as either vagal-dependent or vagal-independent. Among mammals, rabbits and cats belong to the former and guinea-pigs belong to the latter categories. Although insufficient data are available to classify monkeys, dogs and man appear to occupy the middle ground in which a small but significant parasympathetic component modulates airflow-induced bronchoconstriction. The fact that vagal activity can only partially account for airflow-induced bronchoconstriction in some asthmatic subjects suggests that vagal-dependent models may be of limited value in studying the human condition, but should prove valuable in elucidating the parasympathetic component of this mechanism. Although airflow-induced bronchoconstriction appears to be remarkably similar in guinea-pigs, dogs and humans, there are important differences concerning the potential role of specific mediators in producing airflow limitation.

Concordant data from animal models and man suggest that: 1) airflow-induced bronchoconstriction is a basic mammalian response to airway desiccation; 2) airway drying stimulates and cooling inhibits this response; 3) hyperpnoea with dry air may damage the bronchial mucosa and contribute to this response; 4) biochemical mediators contribute to the development of this response; 5) vascular engorgement and airway oedema do not appear to be the primary effectors of this response, and in fact may antagonize it; 6) airway smooth muscle constriction is involved in the production of airflow-induced bronchoconstriction, and airway oedema may enhance its effect; and 7) airway and vascular responses to dehydration may protect against acute dry air-induced mucosal injury.

Finally, although one must be cautious in extrapolating results from animals to humans, the similarities that do exist suggest that the investigation of airflow-induced bronchoconstriction in carefully selected animal models will continue to provide new insights concerning its development in humans.

Eur Respir J., 1995, 8, 1770-1785.
\end{abstract}

Dept of Environmental Health Sciences, The Johns Hopkins Medical Institutions, Baltimore, Maryland, USA.

Correspondence: A.N. Freed

Division of Physiology

7006 Hygiene

The Johns Hopkins University

615 North Wolfe Street

Baltimore

Maryland 21205

USA

Keywords: Airway injury

airway reactivity

bronchoconstriction

bronchovascular hyperpermeability

vascular leakage

Received: April 291994

Accepted after revision July 11995

About 1,800 yrs ago, Aretaeus (120-200 AD) noted that physical exertion provoked airway obstruction [1]; 300 yrs have past since FLOYER [2] speculated as to its cause, and 50 yrs have elapsed since HERXHEIMER [3] suggested that hyperventilation stimulated airway narrowing. Despite the fact that animals have been used for almost two centuries to help us understand human physiology and disease [4], it is only within the last decade that animal models have been developed to investigate the mechanisms by which hyperventilation results in airway obstruction.

Exercise, hyperventilation, and exposure to frigid air cause a transient increase in pulmonary resistance $(R \mathrm{~L})$ in approximately $75-80 \%$ of patients with asthma [5]. Airway narrowing usually peaks $2-10 \mathrm{~min}$ after exposure to dry air, and spontaneously recovers in 30-60 min (fig. 1). For a fixed level of ventilation, colder, dryer inspired air exacerbates this response, whilst warmer more humidified air reduces its severity. Increasing the duration and strength of the stimulus also increases the magnitude of obstruction (fig. 1c and table 1). Although subtle differences may exist in the underlying mechanism triggered by these stimuli, there are numerous similarities in terms of the time-course of airway narrowing (fig. 1), the degree of evaporative heat and water loss [117], and the efficacy of a wide spectrum of drugs that attenuate their effects (table 1). Because of these similarities, the airway narrowing elicited by these stimuli will be referred to as "airflow-induced bronchoconstriction" (AIB).

The mechanism(s) responsible for AIB are unknown, although several hypotheses offer alternative explanations for its development in asthmatic subjects. One states that drying increases airway fluid osmolality, stimulates local mediator release, and results in airway smooth muscle contraction [30]. Another speculates that rapid airway cooling and rewarming causes bronchovascular hyperaemia and mucosal oedema, and this narrows the bronchial lumen [22]. A third suggests that AIB results from an imbalance between airway 
a)

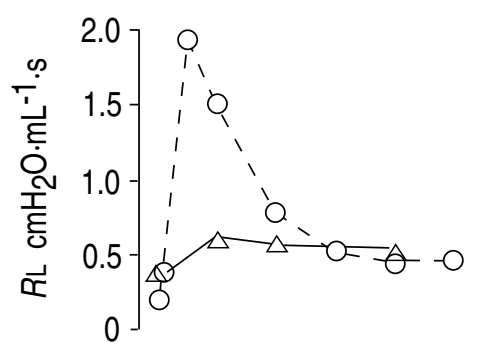

c)

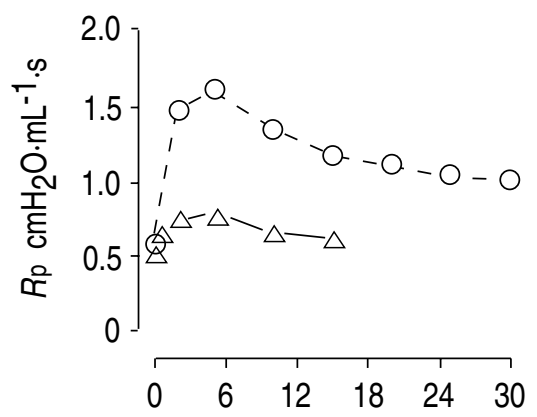

b)

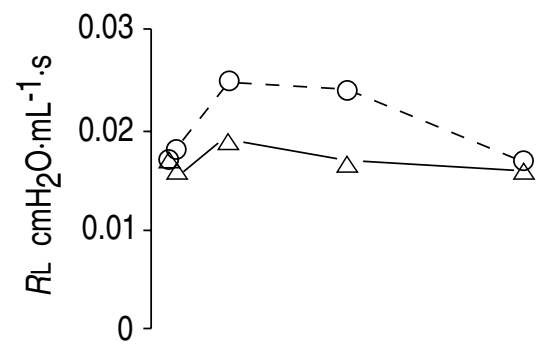

d)

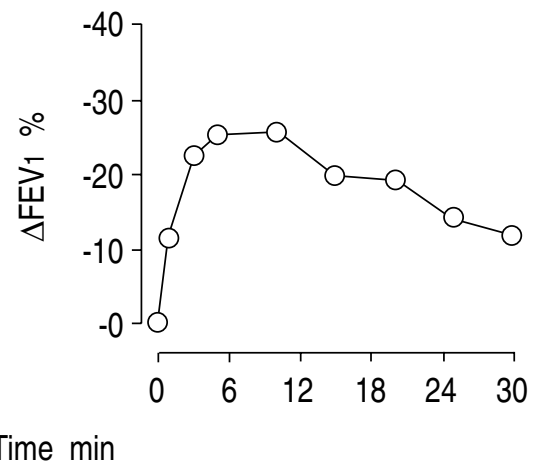

Fig. 1. - Time course for hyperpnoea-induced responses in four mammalian species. Unless otherwise specified, all species were hyperventilated with either dry room air or $5 \% \mathrm{CO}_{2}$ and dry air. a) Guinea-pigs: hyperventilated with dry gas containing $95 \% \mathrm{O}_{2}\left(--\mathrm{O}^{---)}\right.$(data from $\mathrm{RAY}$ et al. [6]); hyperventilated with dry gas containing $21 \% \mathrm{O}_{2}(-\Delta-$ ) (data from CHAPMAN and DANKo [7]). b) Rabbits: sensitized to ovalbumin $\left(--\mathrm{O}^{---}\right.$); nonsensitized ( $-\Delta-$ ) (data from Koyama et al. [8]). c) Dogs: hyperventilated with $2,000 \mathrm{~mL}^{-\mathrm{min}^{-1}}$ for $5 \mathrm{~min}\left({ }^{---\mathrm{O}^{---}}\right.$) (data from FREED and AdKINSON [9]); hyperventilated with $1,500 \mathrm{~mL} \cdot \mathrm{min}^{-1}$ for $2 \mathrm{~min}(-\Delta-$ ) (data from FreED and co-workers [10]). d) Asthmatic humans (data from FINNERTY et al. [11]). RL; pulmonary resistance; $R$ p: peripheral airway resistance (see fig. 2 ); $\Delta$ FEV $1 \%$ : percentage change in forced expiratory volume in one second.

drying, which stimulates, and airway cooling, which inhibits bronchoconstriction [113]. The fact that guineapigs, rabbits, cats, dogs, monkeys, and humans exhibit AIB to varying degrees (table 1) suggests that the physiological response to dry air reflects a basic mechanism that has evolved in mammals to limit exposure of the peripheral airways to provocative stimuli. Thus, the mechanisms that contribute to the aetiology of AIB in humans may not be unique to individuals with asthma. Exercise-induced bronchoconstriction in asthmatics and bronchodilation in normal subjects correlate with inspired water content [73]. This confirms the tendency of normal human airways to narrow in response to hyperventilation [118-120]. The enhancement of AIB in asthmatic as compared to normal humans may reflect the presence of inflammatory mediators and an increased sensitivity to stimuli that are tolerated by normal airways during and after exposure to cool dry air. If this is correct, then understanding the mechanisms responsible for AIB in animal models may help in a better understanding, not only of the responses of normal human airways when exposed to excessive cooling and drying, but also of the exaggerated responses that are exhibited by asthmatic subjects under similar conditions.

The purpose of this review is to compare and contrast AIB in humans and animals, and to evaluate the relevance of each model in terms of its ability to mimic AIB in man. Because of the potential contribution of the bronchial circulation to the development of AIB, considerable attention will be devoted to this area of research. Data from human studies will be examined in the light of relevant data that can be obtained only through the use of animal models.

\section{Animal models and their relevance to AIB in humans}

Most models of AIB are whole animal models, in which both lungs are either exposed to or hyperventilated with cold dry air. An exception is the canine model of AIB, that uses a bronchoscope to isolate and hyperventilate peripheral airways with room temperature dry air (table 1 and fig. 2). All of these models can be criticized for bypassing some part of the upper airways and delivering dry air directly either to the lower trachea or lungs. In addition, the respiratory system of the dog performs a thermoregulatory function, which does not exist in man, and unidirectional airflow in this model eliminates one heat and water recovery mechanism that operates in humans. However, thermoregulation in panting dogs primarily involves the evaporative surfaces of the nose, mouth and tongue [122], which are bypassed in all animal models. DAvisKas et al. [123] calculated 
Table 1. - Characterization of airflow-induced bronchoconstriction in six mammalian species

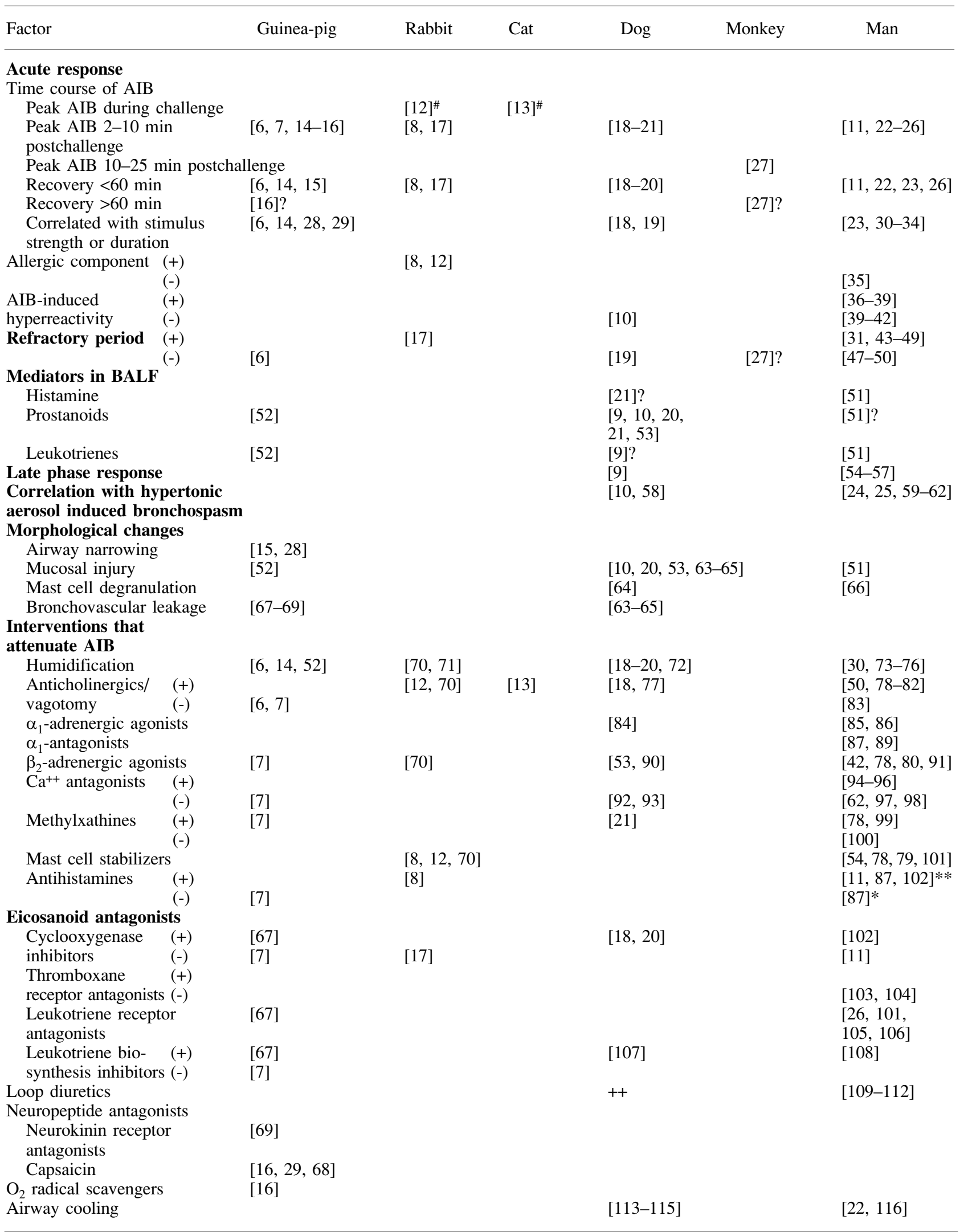

\#: did not examine postchallenge responses; ?: data are suggestive but inconclusive; *: data for exercise-induced responses; **: data for hyperventilation-induced responses; (+): characteristic present or drug beneficial; (-): characteristic absent or drug not beneficial; ++: Omori and Freed, unpublished data. AIB: airflow-induced bronchoconstriction; BALF: bronchoalveolar lavage fluid. 


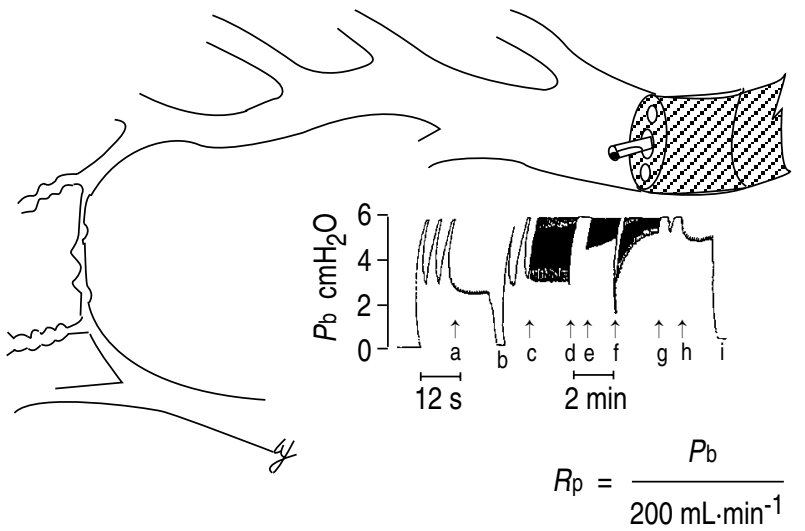

Fig. 2. - Measurement of peripheral airway resistance $\left(R_{\mathrm{p}}\right)$. The diagram depicts the tip of a bronchoscopy wedged in a $5.5 \mathrm{~mm}$ airway. A $5 \mathrm{~F}$ catheter protrudes from its port and is used to deliver $5 \% \mathrm{CO}_{2}$ in air at $200 \mathrm{~mL} \cdot \mathrm{min}^{-1}$ into the wedged sublobar segment, and monitor pressure at the tip of the bronchoscope $(P \mathrm{~b})$. Respiratory bronchioles and alveolar ducts are believed to provide the pathways for collateral flow [121]. $R \mathrm{p}\left(\mathrm{cmH}_{2} \mathrm{O} \cdot \mathrm{mL}^{-1} \cdot \mathrm{s}\right)$ is determined at functional residual capacity, when $P \mathrm{~b}$ plateaus, and the pressure in the surrounding unobstructed lobe is assumed to equal zero. $P \mathrm{~b}$ was recorded as follows: a) the ventilator was stopped, sublobar airflow at this time was $200 \mathrm{~mL} \cdot \mathrm{min}^{-1}$; b) after $P \mathrm{~b}$ plateaued, the transducer was opened to atmospheric pressure; c) the recorded speed was slowed from 10 to 1 $\mathrm{cm} \cdot \mathrm{min}^{-1}$; d) airflow was increased to $1,500 \mathrm{~mL} \cdot \mathrm{min}^{-1}$ for $2 \mathrm{~min}, P \mathrm{~b}$ went off scale; and e) the gain was reduced by $50 \%$; f) airflow was reduced to $200 \mathrm{~mL} \cdot \mathrm{min}^{-1}$ and gain was increased to its original setting, a gradual rise in end-expiratory $P$ b can be seen during the first $2 \mathrm{~min}$ postchallenge; g) the recorder speed was increased; and h) the ventilator was stopped at functional residual capacity. Note that $P \mathrm{~b}$ plateaued at a higher level than when the ventilator was stopped at (a). Zero is checked at (i). (Reproduced from FREED and co-workers [10]).

that during hyperpnoea, the total recovery of heat and water during expiration was $\sim 40$ and $38 \%$ of the heat and water lost during inspiration, respectively. Their model reveals that moving just one generation either up or down the human tracheobronchial tree would alter the local strength of this hydrothermal stimulus (i.e. the amount of heat and water loss) by $40-60 \%$ [123].

Data from man [124] and dog [125] show that the site, magnitude, and mechanisms of respiratory heat and water loss vary with breathing pattern and the condition of inspired gas. However, if different breathing patterns resulted in equivalent local net hydrothermal losses, then the physiological response should be similar. Thus, the use of unidirectional hyperventilation in the canine model would simply increase the stimulus strength at any point along the bronchial tree. This is analogous to increasing bidirectional hyperventilation (via an increase in tidal volume) in guinea-pigs, which would also increase stimulus penetration deeper into the lung [28]. In stressing the analogy between man and dog, it is important to note that the temperature changes that occur during and after normal hyperventilation with subfreezing air in 5th generation human bronchi $(\sim 3.5 \mathrm{~mm}$ in diameter) are similar to the temperature changes that occur during and after unidirectional hyperventilation with room temperature air in canine bronchi of similar size $[18$, 126]. This is a result of using a bronchoscope to bypass large airways and delivering dry room temperature air directly into the lung periphery. Thus, the local stimulus strengths associated with these two different modes of hyperventilation appear to be similar, as are the physiological responses they produce. Despite all of these differences, and the fact that all animals are anaesthetized and either tracheotomized or thoracotomized, their airways respond to excessive cooling and drying in a manner similar to that seen in humans with asthma (fig. 1).

\section{The acute response}

Time-course. In guinea-pigs [14], rabbits [8], and dogs [58] AIB does not usually develop until after hyperpnoea stops. In man, it can occur during exercise [127], but is more common when exercise stops [23]. Thermal [113, 114] and mechanical [14, 23] inhibition that occurs during hyperventilation may account for this delay. Once initiated, the time-course over which AIB develops and subsides in guinea-pigs, rabbits, and dogs is similar to that seen in humans (fig. 1), and their responses to variations in stimulus strength and duration are also analogous (table 1). However, rabbits appear to be less sensitive to dry air challenge than either guinea-pigs, dogs, or asthmatic humans (fig. 1). AIB also occurs in cats [13] and monkeys [27]. Although $R \mathrm{~L}$ was not recorded in cats for more than a few minutes after cold air challenge, it fell to about $50 \%$ of maximum within $3 \mathrm{~min}$ after rewarming occurred. Thus, the time-course in this species appears to be considerably shorter than in other models, and may reflect differences in either the challenge or the underlying mechanism. In contrast, AIB appears to develop more slowly in monkeys, with maximum changes in $R \mathrm{~L}$ occurring around $25 \mathrm{~min}$ after exposure, compared to the 2-10 min usually reported for guineapig, rabbit, dog and man (fig. 1 and table 1).

Allergic component. Although AIB and allergy appear to be independent traits [35], increased bronchial responsiveness to exercise does occur after allergen provocation in children with asthma [128]. The rabbit is unique among animal models of AIB in that hyperventilation with room temperature dry gas elicits significant airway obstruction only in sensitized animals (fig. 1b). Sensitized rabbits were hyperresponsive to histamine, and exhibited enhanced response to cold air when compared to normal rabbits (table 1). It is unknown whether sensitization and allergen provocation would enhance AIB in other animal models.

AIB-induced hvperreactivity. The acute effect of exposure to cool dry air on human airway responsiveness, either at rest or during hyperventilation, is unclear. Several laboratories have reported that after exercise whilst breathing cold, dry air neither normal nor asthmatic subjects exhibited enhanced responsiveness to either inhaled histamine or methacholine. In contrast, other laboratories have reported that breathing cold dry air increased airway reactivity in normal and asthmatic subjects (table 1). Differences in patient population, methods of exposure, or the methods used in evaluating pulmonary 
function may account for this discrepancy. Post-AIB airway hyperreactivity has been investigated only in dogs, which do not exhibit hyperreactivity after dry air challenge [10].

\section{The refractory period}

Asthmatic subjects with AIB can be classified as either refractory or nonrefractory (table 1). Individuals who exhibit a refractory period experience less obstruction in response to repetitive challenge. The presence of a refractory period appears to be independent of the magnitude of obstruction provoked by the first challenge [129], and inversely related to the time separating any two consecutive challenges [31]. Studies examining the effect of indomethacin in man [43, 44] and sensitized rabbit [17] suggest that refractoriness to repeated bouts of exercise and hyperpnoea, respectively, is dependent on the generation of bronchodilating prostaglandins. However, indomethacin appears to be ineffective in blocking refractoriness to hyperpnoea in asthmatic subjects [44]. This is one of the few inconsistencies that distinguish exercise- from hyperpnoea-induced responses in man; the other being the ability of antihistamine to inhibit exercise- but not hyperpnoea-induced airway obstruction [87]. In addition, although a histamine $\mathrm{H}_{2}$ receptor antagonist had no effect on exercise-induced refractoriness in humans [45], it abolished hyperpnoeainduced refractoriness in rabbits [17]. These discrepancies suggest that the refractory period in these two species result from different underlying mechanisms. Other studies of asthmatic subjects indicate that exercise-induced refractoriness is associated with a leukotriene-induced release of inhibitory prostaglandins [46], but it remains to be determined if this potential interaction also influences hyperpnoea-induced refractoriness in rabbits.

It is important to note that refractoriness is expressed in about half of the asthmatic patients that exhibit AIB [47-49], and as such is not a universal characteristic of the human condition. BELCHER et al. [48] reported that $40 \%$ of their asthmatic subjects were refractory to exercise and hypertonic aerosol challenge, and were also cross-refractory to these stimuli. However, $60 \%$ of their subjects were not refractory to either stimulus, and were not cross-refractory to these stimuli. Similar results were reported for dogs, which were neither refractory nor cross-refractory to dry air [18-20] and hypertonic aerosol challenges $[10,58]$. If the mechanism responsible for refractoriness is related to the initiation of AIB, then nonrefractory guinea-pig, dog, and monkey models may be relevant only to the subset of asthmatic humans who are nonrefractory (table 1).

\section{Biochemical mediators recovered in bronchoalveolar lavage fluid (BALF)}

Although a variety of biochemical mediators have been implicated in the development of AIB in humans and animals (table 1), there is little direct evidence to support their role in the development of AIB. PLISS et al.
[51] reported that isocapnic hyperpnoea increased the concentrations of leukotrienes in BALF recovered from asthmatic patients, although this was not confirmed in similar studies by other investigators $[130,131]$. Possible explanations for this apparent discrepancy will be discussed under the subheading "Evidence for biochemical mediators in the development of AIB". It is important to note that similar experiments performed in dogs $[9,20,21,53]$ and guinea-pigs [52] did show that eicosanoids were elevated immediately after hyperventilation.

\section{The late phase response}

Although a decrease in airway function $3-13 \mathrm{~h}$ after exercise is well-documented in asthmatic individuals (table 1), the mechanism responsible for this delayed response is the subject of great debate [66, 132, 133]. A cellular basis for this late event has not been demonstrated in man, although neutrophil chemotactic activity has been detected in the plasma of asthmatic subjects during this response [134]. The fact that a purported mast cell "stabilizing" drug attenuated the delayed response to exercise [54] suggests that mediator release contributes to its development, which is believed to primarily involve small airways [135]. A late increase in peripheral airway resistance $(R \mathrm{p})$ in the canine model is analogous to that reported in humans, and is characterized by neutrophil and eosinophil infiltration, and an increased concentration of leukotriene $\mathrm{C}_{4} / \mathrm{D}_{4}$ in BALF recovered from dry air-exposed bronchi [9].

\section{Hypertonic aerosol-induced bronchoconstriction (HAIB)}

Numerous studies have revealed that hypertonic aerosol challenge produces varying degrees of airway obstruction in asthmatic subjects, and these responses are significantly correlated with AIB (table 1). There also exists a strong positive correlation between HAIB and AIB in dogs. However, unlike AIB, HAIB in both species normally occurs in the absence of airway cooling and peaks immediately after challenge $[10,24,58]$. This difference in time-course appears to be unrelated to stimulus strength [10], but may result from the differential activation or inactivation of biochemical pathways by these two stimuli. The implications of these observations will be discussed under "Roles for airway cooling and drying in the development of AIB".

\section{Morphological changes associated with AIB}

Airway narrowing. Hyperpnoea-induced airways constriction in guinea-pigs was directly measured via morphometric analysis [15], and tantalum bronchography [28]. Central airway narrowing was prominent after mild hyperpnoea, and peripheral airway constriction occurred after more severe challenge. These findings are consistent with the post-hyperpnoea partitioning of $R \mathrm{~L}$ 
in man, suggesting mild central airway narrowing in normal subjects [118, 119], and severe peripheral airway obstruction in asthmatic individuals [136, 137]. In addition to airway narrowing, increases in pulmonary tissue resistance and distortion appear to contribute to AIB in guinea-pigs [15]. The relevance of these tissue events to the development of AIB in other models and man requires investigation.

Mucosal injury. Bronchoalveolar lavage (BAL) studies of guinea-pigs, dogs and humans suggest that mucosal injury is associated with AIB (table 1). Morphometric analysis of canine bronchi confirms this hyperpnoeainduced mucosal damage $[63,64]$. Increasing the flow rate of dry air from 1,000 to $2,000 \mathrm{~mL} \cdot \mathrm{min}^{-1}$ increases the magnitude of AIB, but only the higher flow rate results in greater penetration of the dry air stimulus and marked mucosal injury [63]. Warm-wet air attenuates AIB in guinea-pigs, rabbits, dogs and man (table 1), and based on BALF cell profile data [20], and image analysis of dry and wet air challenged bronchi in dogs [63], reduces dry air-induced mucosal injury. Pretreatment with $\beta$-agonists also protect the canine mucosa from injury when compared to untreated dry air challenged segments (table 1). Conditioning of the inspired air simply reduces the strength of the stimulus, whereas $\beta$-agonists may decrease airway desiccation (and damage) by increasing fluid flux across the bronchial mucosa [53, 138].

Mast cell degranulation. Mast cell degranulation was evident in bronchial biopsy specimens $3 \mathrm{~h}$ after asthmatic subjects exercised [66]. Morphometric analyses of canine bronchial tissues also revealed that mast cell degranulation occurred either during or immediately after hyperpnoea with dry air [64]. Numerous other studies indirectly implicate mast cell degranulation in the development of AIB, and these will be discussed under the subheading "Interventions that attenuate AIB".

Bronchovascular leakage. It is unknown whether or not bronchovascular leakage occurs in humans during AIB. However, the fact that hyperpnoea with dry air causes bronchovascular hyperpermeability in animals (table 1) suggests that this association is likely to be found in man. Bronchovascular leakage represents a useful subepithelial marker of perturbation in canine peripheral airways [63]. In dogs, leakage occurs immediately after hyperpnoea ceases, leucocyte infiltration begins 1-2 h later, and both continue for at least $24 \mathrm{~h}$ after the initial exposure [64]. Although few data exist concerning the association between vascular leakage and AIB, guinea-pig [67] and canine [64, 84] data suggest that changes in bronchovascular permeability are unlikely to contribute to the development of AIB. It remains to be determined whether or not these changes contribute to the late response that is evident $5 \mathrm{~h}$ after dry air challenge in dogs [9]. This prolonged late response is of particular interest in light of the hypothesized contribution of persistent obstruction to the recurrence of asthma attacks in humans [139].

\section{Interventions that attenuate $A I B$}

Pretreatment with anticholinergics, $\alpha_{1}$-adrenoreceptor agonists and antagonists, $\beta_{2}$-agonists, $\mathrm{Ca}^{++}$antagonists, methylxanthines, mast cell stabilizers, antihistamines, cyclooxygenase inhibitors, thromboxane and leukotriene receptor antagonists, leukotriene biosynthesis inhibitors, loop diuretics (table 1), mu opioid receptor antagonist [140], platelet-activating factor (PAF)-antagonist [141], and corticosteroid [142] provide some asthmatic individuals with at least partial protection against AIB. Although some of these effects result from either nonspecific or unknown modes of action, these varied and sometimes contradictory findings suggest that AIB does not result from a single mechanism in an individual asthmatic, nor from the same mechanisms in all asthmatics. Thus, differences in the mechanisms responsible for AIB in different animal models may be useful in delineating the mechanisms that contribute to the development of AIB in the heterogeneous group of humans collectively referred to as asthmatic.

Humidification. As in asthmatic subjects, exercise or hyperventilation with warm-humid air inhibits AIB in every animal model studied (table 1). Conditioning of the inspired air apparently reduces the magnitude of the stimulus and its penetration into the lung periphery.

Anticholinergics. Most studies indicate that a parasympathetic reflex pathway plays a small but significant role in the development of AIB in some asthmatic subjects (table 1), and about $60 \%$ of all asthmatic children that exhibit AIB benefit to some degree from treatment with a parasympatholytic agent [78]. Although guinea-pigs lack this parasympathetic component, rabbits, cats, and dogs exhibit it to varying degrees: AIB is mildly attenuated in dogs, but completely abolished in rabbits and cats, by either muscarinic antagonists or vagotomy (table 1). This indicates that rabbits and cats are not suitable for studying the nonvagal residual component that characterizes AIB in human asthmatics. The fact that a parasympathetic component can only partially account for AIB in some but not all asthmatic individuals further suggests that rabbits and cats may provide a limited model for studying the human condition. However, within this context, these models will probably provide important insights concerning the vagally-mediated component of AIB.

$\alpha_{1}$-adrenergic agents. Considerable confusion surrounds the role of $\alpha$-adrenoceptor activity in AIB, because both $\alpha$-adrenergic agonist and antagonist drugs appear to inhibit this response (table 1). Early studies using antagonists were based on the assumption that dry airinduced stimulation of $\alpha_{1}$-receptors resulted in bronchoconstriction. Later studies using agonists focused on their potential role in stimulating vasoconstriction [143], which can theoretically inhibit AIB either by reducing mucosal swelling or increasing mucus secretion. The former may reduce airway obstruction, whereas the latter may reduce evaporative water loss during challenge. 
Some of these studies will be discussed in greater detail under the subheading "Roles for airway and vascular smooth muscle in the development of AIB".

$\beta_{2}$-adrenergic agonists. Beta $a_{2}$-adrenoreceptor agonists are potent inhibitors of AIB in guinea-pigs, rabbits, dogs and man (table 1). These drugs are believed to act either by reducing smooth muscle responsiveness, inhibiting mediator production and release from effector cells, or facilitating the replacement of water lost during exposure to dry air [53]. Beta 2 -agonists will be discussed again under the subheading: "Roles for airway and vascular smooth muscle in the development of AIB".

Calcium antagonists. Voltage sensitive calcium channel (VSCC) blocking drugs are completely ineffective in dogs and guinea-pigs, and are at best inconsistent in their ability to attenuate human AIB (table 1). Some human studies reveal that $\mathrm{Ca}^{++}$antagonists either completely or partially inhibit AIB, whereas others directly contradict these observations (table 1). Even in studies demonstrating statistically significant effects, not all individuals benefit from treatment [94-96]. Those that do, may benefit from the drug's circulatory effects, which could enhance either air-conditioning or mediator clearance.

Methylxanthines. Studies of asthmatic humans, dogs and guinea-pigs reveal that xanthine derivatives provide moderate protection against AIB (table 1). Although their mode of action remains uncertain, methylxanthines may inhibit phosphodiesterase, adenosine receptor, or mast cell activity, and increase circulating catecholamines. Aminophylline is ineffective in reducing either mediator release or smooth muscle responsiveness in dogs, but does elevate airway wall temperature during hyperpnoea [21]. These data suggest that methylxanthines may, in part, inhibit AIB by reducing evaporative heat and water loss during hyperpnoea.

Mast cell stabilizers. Disodium cromoglycate and nedocromil sodium significantly inhibit AIB in asthmatic subjects. Rabbits, the only animal model in which cromolyn has been tested, also derive significant protection against AIB from this drug (table 1). These studies are generally cited as evidence supporting a role for mediator release in the development of AIB. However, in addition to the purported efficacy of these drugs in "stabilizing" mast cells and inhibiting mediator release, they may also inhibit the afferent limb of a vagal reflex [144, 145]. This is particularly important in the rabbit model, which is completely vagal-dependent.

Antihistamines. Most but not all studies of asthmatic subjects implicate a role for histamine in AIB (table 1). Terfenadine inhibits AIB [102] and HAIB [146] similarly. Studies of allergic rabbits also implicate a role for histamine in AIB (table 1). However, chlorpheniramine was used to inhibit $\mathrm{H}_{1}$-receptors in the rabbit [8], and this drug can also inhibit vagal activity [147]. In contrast, AIB in guinea-pigs appears to be independent of histamine (table 1).
Eicosanoid antagonists. The mediation of AIB by metabolites of arachidonic acid was first described in dogs, and later confirmed in guinea-pigs and asthmatic humans. Other studies have also implicated peptidoleukotrienes in the development of AIB in these three species (table 1). Although hyperpnoea-induced generation of eicosanoids may directly initiate AIB, recent experiments suggest that eicosanoids may modulate AIB in guinea-pigs by influencing airway C-fibre neuropeptide secretion [67].

Loop diuretics. The loop diuretic, furosemide, inhibits AIB in humans and dogs when administered as an aerosol to the mucosal surface (table 1). Furosemide may do so by inhibiting airway sensory nerves [148], stabilizing mast cells [149], stimulating prostaglandin release [109], or producing local vasodilation [110]. In addition, it inhibits epithelial cell $\mathrm{Na}^{+}-\mathrm{Cl}^{-}$and $\mathrm{Na}^{+}-\mathrm{K}^{+}-2 \mathrm{Cl}^{-}$ co-transport, and may provide protection against AIB by reducing intraepithelial water loss.

Neuropeptide antagonists. Although no evidence yet exists for the participation of neuropeptides in human AIB, tachykinins appear to be key mediators of hyperpnoea-induced responses in guinea-pigs $[68,69]$. Thus, the endogenous release of tachykinins may also play an important role in the development of AIB in other species, including man. However, the tracheobronchial tree of guinea-pigs exhibit about 10 times more tachykinin immunoreactivity than do human bronchi [150]. Tachykinin receptors are sparsely distributed on the airway smooth muscle and epithelium in man [151], and substance $\mathrm{P}$ is about 1,000 times less potent in isolated human airway than in guinea-pig trachea [152]. Thus, significant differences in the modulatory role of neuropeptides may exist among different species.

Neurokinin (NK)-1 and NK-2 receptor antagonists inhibit AIB in guinea-pigs by 50 and $70 \%$, respectively [69]. This and other studies suggest that dry gas hyperpnoea with $95 \% \quad \mathrm{O}_{2} / 5 \% \quad \mathrm{CO}_{2}$ causes bronchoconstriction in guinea-pigs through the activation of tachykinin receptors $[29,68]$. Neither ganglionic blockade nor the abolition of nerve impulse conduction alters AIB in this model, suggesting that tachykinins are released directly from afferent C-fibres [16]. The fact that NK-receptor antagonists do not abolish AIB in guinea-pigs [69] suggests that other mediators or mechanisms account for the residual component in this model. The magnitude of AIB (measured as an increase over baseline resistance) elicited from guinea-pigs hyperventilated with hyperoxic gas $[6,15]$ tends to be markedly greater than that reported for either this species [7, 52], or other species $[8,9,12,13]$, hyperventilated with normoxic gas (fig. 1 ). This difference may result from the generation of $\mathrm{O}_{2}$ radicals produced during hyperoxic hyperventilation. $\mathrm{O}_{2}$ radicals appear to enhance AIB in guinea-pigs by augmenting the release of tachykinins during hyperpnoea [16]. However, the interaction between $\mathrm{O}_{2}$ radical production and tachykinin release cannot account for the residual component of AIB in this model. 


\section{Mechanisms that contribute to the development of AIB}

Roles for airway cooling and drying in the development of $A I B$

Exercise, hyperventilation of dry air, and inhalation of hypertonic aerosols produce similar responses in most asthmatic subjects $[24,25,59]$. The fact that AIB correlates with HAIB in human and canine airways (table 1) supports the hypothesis originally proposed by ANDERSON et al. [30] that hyperpnoea-induced airway hyperosmolality initiates AIB. The fact that a hypertonic stimulus causes mast cell mediator release in vitro [153] is consistent with this hypothesis, although its effects in vivo

a)
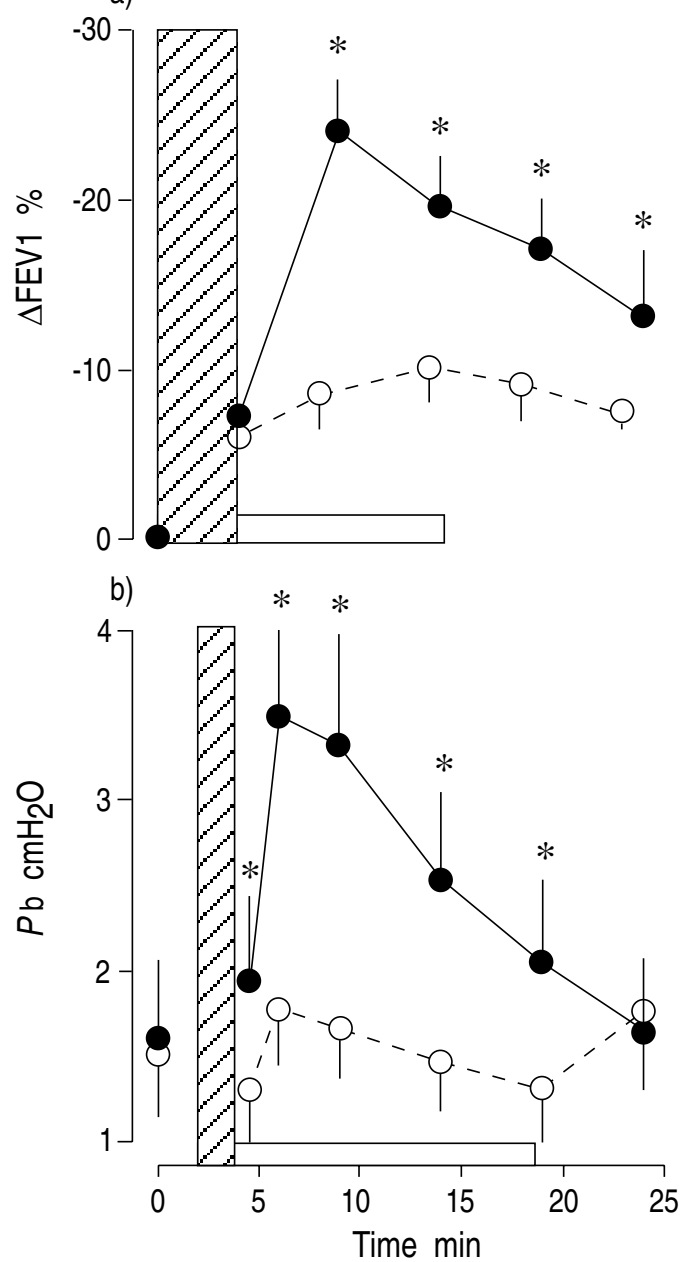

Fig. 3. - a) Percentage change in forced expiratory volume in one second $\left(\triangle \mathrm{FEV}_{1} \%\right)$ in asthmatic humans $(\mathrm{n}=8)$ during recovery from cold air hyperpnoea while breathing room temperature ( -- ) or cold (--.--) air for about $10 \mathrm{~min}$ after challenge. Vertical bar: 4 min of hyperpnoea with cold air; horizontal bar: approximate time subjects breathed cold air after hyperpnoea ended. (Data from MCFADDEN et al. [22]). b) Sublobar pressure $(P \mathrm{~b})$ in canine bronchi $(\mathrm{n}=7)$ before and during recovery from dry air hyperpnoea at body temperature $\left(\longrightarrow\right.$ ) or when bronchi were cooled to $30^{\circ} \mathrm{C}$ (--..-.-.) during and for $15 \mathrm{~min}$ after challenge. Vertical bar: $2 \mathrm{~min}$ of hyperpnoea with dry air; horizontal bar: time after hyperventilation that sublobar bronchi were cooled. (Data from FREED and co-workers [113]). Values are presented as mean \pm SEM. *: $\mathrm{p}<0.05$. remain unclear [154, 155]. Data from man and dog reveal that the stimulatory effects of evaporative water loss may be counterbalanced by an inhibitory pathway associated with airway cooling, and further alludes to the complexity of this process (table 1). Figure 3 shows that when either asthmatic (fig. 3a) or canine bronchi (fig. $3 \mathrm{~b}$ ) are challenged and allowed to recover under normal conditions, airway obstruction develops and peaks between 2-6 min after hyperpnoea stops. In contrast, when airway cooling continues after hyperpnoea ceases, airway obstruction is significantly reduced in man and dog. This suggests that both airway cooling and rewarming may be necessary for the initiation of AIB [22]. However, AIB does not develop in canine airways when cooling and rewarming occur in the absence of hyperpnoea-induced airway drying (fig. 4).

a)

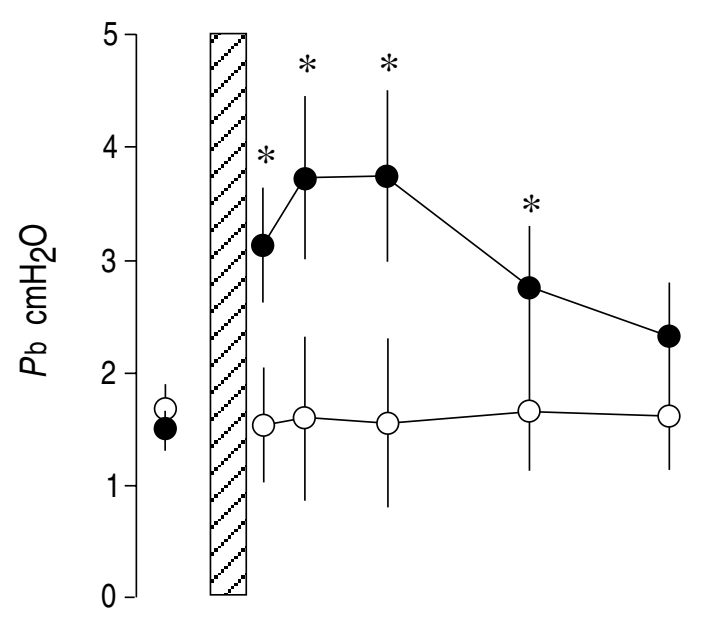

b)

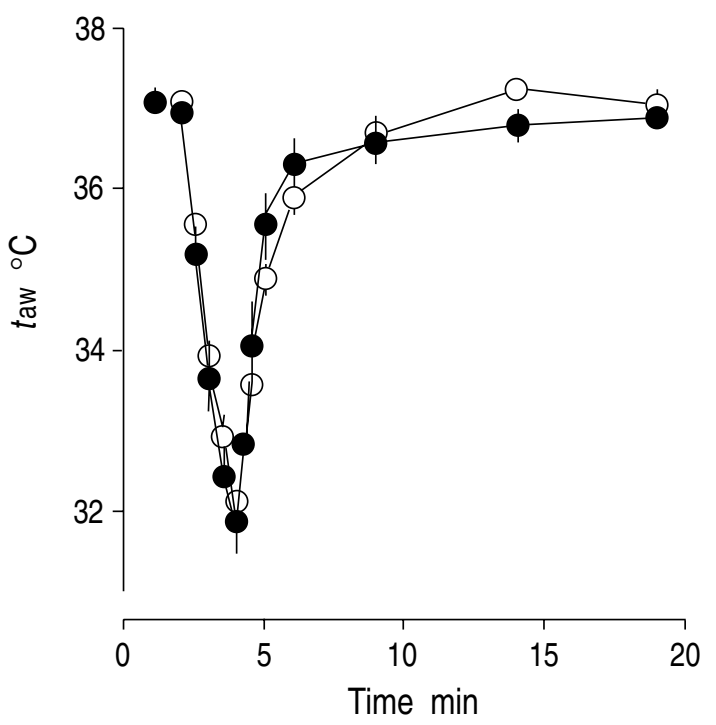

Fig 4. - a) Sublobar pressure $(P b)$ for consecutive exposures of the same sublobar segment to either pulmonary perfusion with cold blood ( $\_-$- $)$or to dry air challenge ( $\_$). Vertical bar: 2 min period of exposure to either dry air or cold blood. b) Airway wall temperatures $(t$ aw $)$ are recorded before, during, and after challenges shown in (a). Values are presented as mean $\pm \operatorname{sem},(n=6)$. *: $p<0.05$. (Data from FREED and co-workers [113]). 
Although one must be cautious in extrapolating results from animals to humans, figures 1, 3 and 4 confirm that canine and human airways respond similarly to hyperpnoea, and demonstrate that abrupt changes in airway temperature are not a prerequisite for the initiation of AIB. In fact, data from adult man and dog (table 1) are consistent with the hypothesis that airway cooling per se inhibits hyperpnoea-induced airway obstruction during challenge, possibly by reducing neuronal activity or mediator release. However, Sмітн et al. [156] were unable to demonstrate any effect of temperature on exercise-induced responses in children with asthma, suggesting that this mechanism may not be a universal characteristic of all subjects that exhibit AIB.

If drying alters periciliary, paracellular, or intracellular fluid osmolality to initiate AIB, and if cooling antagonizes this response, then the time course of AIB and HAIB should be similar, and should be similarly antagonized by airway cooling. Although airway cooling does inhibit canine AIB and HAIB [114], HAIB in man [24] and dog [58, 114] appears to develop during and not after the exposure. The fact that transient airway cooling during hypertonic aerosol challenge delays the onset of HAIB in dogs [114] suggests that hyperpnoeainduced cooling may delay the onset of AIB via the inhibition of either mediator or neuronal activity. This also implies that dry air and hypertonic aerosol may activate portions of the same regulatory pathway. Interestingly, atropine attenuates canine AIB [18] and HAIB [58] by $\sim 30$ and $\sim 60 \%$, respectively, and dry air challenge appears to induce greater mediator release than that produced by hypertonic aerosol challenge [10]. These observations imply that although AIB and HAIB may result from the activation of common, pathways, dry air and hypertonic stimuli differentially activate mediator release and neuronal activity.

The role of dry air-induced mucosal injury, a characteristic of AIB in guinea-pig, dog and man (table 1), has been all but ignored as either a potential initiating or contributing factor in the development of AIB. Analysis of cells recovered in BALF samples from dogs suggest that exposure to hypertonic aerosols may also produce mucosal injury [10]. It is possible that either direct mucosal cell stimulation or damage may independently initiate AIB via the release of epithelial cell-derived mediators, and that airway cooling may moderate dry airinduced injury by "stabilizing" ciliated, secretory, and mediator releasing cells.

Evidence for biochemical mediators in the development of $A I B$

The role of biochemical mediators in the development of hyperpnoea- and exercise-induced asthma remains controversial. Although a post-hyperpnoea increase in BALF eicosanoids recovered from guinea-pigs, dogs, and asthmatic humans does not address the issue of cause and effect, it does implicate mediator activity in the development of AIB (table 1). However, other studies of asthmatic subjects, notably those involving exercise, fail to detect any change in mast cell-derived mediators during AIB [130, 131]. Although bronchial blood flow increases during hyperventilation [157-159], exercise may increase it even further. In comparison to the post-hyperpnoea condition, an exercise-enhanced bronchial circulation may augment mediator clearance [160, 161], and account for the discrepancy between exercise- and hyperpnoea-based studies. Other discrepancies, such as those between BALF mediator data and the action of specific mediator antagonists (table 1), emphasize the fact that BALF-derived data may not adequately reflect mediator activity within the bronchial mucosa. Thus, the histological documentation of mast cell degranulation [64, 66] and the reported efficacy of mast cell stabilizing, biosynthesis inhibiting, and receptor blocking drugs in attenuating AIB in man, dog, rabbit, and guinea-pig (table 1) represent the strongest evidence that biochemical mediators contribute to the development of AIB.

Although an early study reported that pretreatment with aerosolized vasoactive intestinal peptide (VIP) did not protect asthmatics against AIB, VIP did tend to increase peak expiratory flow rates after exercise [162], and inhibited bronchial reactivity to histamine [163]. These observations, in conjunction with the fact that exogenous VIP inhibits canine AIB [77], suggest that the endogenous release of VIP may normally antagonize AIB. The fact that tryptase can rapidly hydrolyse VIP suggests that the dry air-induced release of this mast cell enzyme may also contribute to AIB [164]. Although tryptase inactivates VIP it does not hydrolyse tachykinins [164], and as such may enhance the role of these mediators in AIB. Endothelin is another peptide that may contribute to AIB. It is produced by epithelium and endothelium alike, and can increase smooth muscle tone and microvascular permeability [165]. Other potential contributors include numerous cytokines, which are produced by stimulated airway epithelial cells [166, 167], and are involved in many aspects of the acute-phase response to infection and injury [168]. Finally, the fact that nitric oxide $(\mathrm{NO})$ can attenuate methacholine-induced bronchoconstriction in guinea-pigs and man [169, 170], and NO synthesis inhibitors can enhance airway reactivity in guinea-pigs [171], raises questions concerning its potential role in AIB. The development and use of highly specific receptor blockers or enzyme inhibitors will ultimately determine the direct and indirect actions of these substances, and the consequences of their metabolic activities on the development of AIB.

Roles for airway smooth muscle and vasculature in the development of $A I B$

Beta $_{2}$-adrenoreceptor agonists are among the most effective inhibitors of AIB (table 1), and are believed to act primarily by reducing smooth muscle responsiveness. It is the efficacy with which these drugs protect against AIB and the speed with which AIB develops and subsides (table 1) that have convinced many investigators that mediator-induced smooth muscle contraction is the primary cause of hyperpnoea-induced bronchial 
obstruction. However, MCFADDEN et al. [22] speculated that airway obstruction resulted from cooling-induced vasoconstriction of the bronchial vasculature. This hypothesis was based on the assumptions that airway cooling transiently decreased bronchial blood flow and that a rewarming-induced hyperaemia resulted in bronchovascular engorgement and airway oedema that narrowed the bronchial lumen. The use of intravascular radiolabelled microspheres to measure airway blood flow in dogs and sheep revealed that bronchial blood flow increased during periods of hyperpnoea with dry air [157159]. BAILE et al. [157] found that hyperventilation with warm, dry air produced a greater increase in airway blood flow than hyperventilation with cold, dry air, and suggested that airway drying was the primary stimulus for increasing blood flow. The local release of vasodilatory prostaglandins and neuropeptides was implicated in the modulation of this vascular response to dry air [158]. Although airway drying has been hypothesized to stimulate airway constriction via an increase in airway surface fluid osmolality [30], delivering a hypertonic aerosol into the airway lumen did not alter tracheobronchial blood flow in dogs [172]. This suggests that if dry airinduced hyperosmolality increased tracheobronchial blood flow, then either its site of action or access differs from that resulting from a hypertonic aerosol challenge. Although animal data do not support the original hypothesis that cooling induces airway vasoconstriction, they do not rule out the possibility that bronchovascular hyperaemia and oedema formation contributes to the development of AIB [22].

If bronchovascular hyperaemia does contribute to the development of AIB, then $\alpha_{1}$-adrenoreceptor agonists, which presumably cause bronchovascular constriction, should inhibit airway obstruction. Pretreatment with the $\alpha_{1}$-agonist methoxamine (MX) did protect individuals exhibiting mild airway obstruction, but failed to alter the more severe responses to exercise challenge [85]. MX was not very impressive in attenuating AIB in dogs either [84]. Inhalation of noradrenaline (NA) produced more impressive results: GILBERT and McFADDEN [86] suggested that the magnitude of cooling was linearly related to bronchial narrowing, and that the drug-induced reduction of airway mucosal blood flow limited the obstructive process. However, similar experiments performed in $\beta$-blocked dogs suggest that NA attenuated human AIB by inhibiting airway smooth muscle contraction, and not by stimulating bronchial vasoconstriction [84]. In addition, BLosser et al. [173] revealed that when bronchial blood flow in sheep was elevated $300 \%$ above baseline for $3 \mathrm{~h}$, despite vascular engorgement and oedema formation, airway resistance remained unchanged [173].

In an attempt to demonstrate that vascular engorgement and fluid extravasation could influence hyperpnoeainduced alterations in the pulmonary function of asthmatic subjects, experiments were performed in which either blood volume was acutely shifted from the legs into the thorax via anti-shock trousers [174], or warm saline was rapidly infused to expand intravascular volume [175]. In asthmatic subjects, volume expansion with saline produced pulmonary obstruction similar to that seen with hyperventilation. This obstruction was blunted when saline was infused before hyperpnoea, and was enhanced when saline was infused late in the challenge [175]. The shifting of blood into the thorax during hyperventilation also attenuated the obstructive response and slowed the rate of rewarming [174]. Similar volume expansion studies were performed in dogs: loading with normal saline increased pulmonary capillary wedge pressure (PCWP) and increased $R$ p. Unlike saline, Dextran 70 (a polysaccharide which is hyperoncotic to plasma) did not increase $R \mathrm{p}$ when infused at a rate that produced similar changes in PCWP [176].

These results suggested that oedema formation and not vascular engorgement was responsible for the rise in $R \mathrm{p}$ caused by saline infusion. In addition, as reported in asthmatic subjects [175], hyperpnoea with dry air prior to saline infusion enhanced airway obstruction [176]. These observations suggest that any protection derived by expanding the pulmonary fluid reservoir is time- or injury-dependent. These data are consistent with the hypothesis that hyperpnoea-induced bronchovascular leakage inhibits AIB by counterbalancing the evaporative water loss that occurs during and immediately after exertion. If this is correct, then intravascular plasma expansion before challenge should contribute to the maintenance of airway fluid balance during hyperventilation. If hyperpnoea with dry air increases microvascular permeability, as suggested, then volume loading after hyperpnoea should exacerbate AIB by contributing to airway oedema [175]. Thus, although both intravascular volume expansion and hyperpnoea are stimuli that can alter airway function, there is no evidence to suggest that the mechanisms responsible for fluid loading-induced airway obstruction contribute to the development of AIB.

Studies examining dry air-induced bronchovascular leakage in guinea-pigs [68] and dogs [63] suggest that a dry air-induced increase in bronchial blood flow [157, $158]$ is accompanied by an increase in bronchovascular permeability and a concomitant movement of extravasated fluid into the airway wall. Vascular congestion may increase capillary hydrostatic pressure via the bronchial circulation, increase fluid exudation, and cause airway oedema [173, 177, 178]. However, the fact that bronchovascular hyperpermeability in dogs persists for at least $24 \mathrm{~h}$ after hyperpnoea [64] suggests that the transient and reproducible bronchoconstriction that characterizes AIB in this model [19] is unlikely to be a consequence of this ongoing vascular response. Morphometric analysis of guinea-pig bronchi further suggests that smooth muscle constriction, and not airway wall oedema, is responsible for hyperpnoea-induced airway narrowing [15]. In addition, although eicosanoid and tachykinin antagonists in guinea-pigs and $\beta_{2}$-receptor agonists in dogs significantly attenuate AIB (table 1 ), they do not alter hyperpnoea-induced vascular leakage in these species [67, 69, 179]. Finally, ligation of the bronchial artery during hyperpnoea abolishes bronchovascular leakage and increases mucosal injury, but fails to affect hyperpnoea-induced airway obstruction in dogs [65]. This finding represents the first direct demonstration that blood 
flow within the bronchial circulation does not determine the magnitude of AIB. Thus, AIB and bronchovascular leakage appear to be independent events.

Considering the dearth of data directly demonstrating a role for the bronchial circulation in the development of AIB, it seems reasonable to hypothesize that the airway and vascular responses to dehydration may actually protect the bronchial mucosa from acute injury [180]. The fact that excessive airway drying stimulates secretory and mast cell degranulation, and results in mucus secretion, smooth muscle constriction and bronchovascular hyperpermeability in normal canine bronchi $[63,64]$ suggests that, under appropriate conditions, these events may also occur in normal humans. An increase in smooth muscle tone would narrow the airway lumen, and not only reduce the penetration of cool dry air, but reduce the mucosal surface area exposed to this insult. Figures 3 and 4 reminds us that in vivo cooling inhibits dry air-induced constriction of canine and human airways, and under normal circumstances may provide negative feedback to limit the development of AIB. The fact that during a post-exercise recovery period the tracheae of normal subjects rewarm more slowly than those of asthmatic individuals [181] is consistent with the hypothesis that airway cooling modulates smooth muscle responsiveness in normal man. With regard to airway dehydration, bronchovascular leakage may replace water lost from the mucosa, which in turn would help to maintain mucosal hydration above a critical level. Alternatively, assuming that the hyperpnoea-induced increase in bronchial blood flow [157-159] was accompanied by an increase in bronchovascular permeability (table 1), movement of extravasated fluid towards the airway lumen may increase the clearance of mediators $[160,161]$ released either during or after hyperpnoea. It is interesting to speculate that the high prevalence of asthma in endurance athletes [182, 183] is a result of repeatedly overwhelming the mechanisms that protect against dry air-induced mucosal injury. If repeated injury in susceptible individuals results in chronic inflammation, then repeated exposure to dry air may contribute to the pathogenesis of asthma.

In conclusion, exercise, hyperpnoea, or exposure to cold dry air increases airway resistance and damages the bronchial mucosa in animals and man. Exposure to dry air also increases bronchovascular permeability in guineapig and dog, and there is little reason to believe that this association does not occur in humans. Data from animal and human studies suggest that AIB and bronchovascular leakage are a consequence of two independent mechanisms. Instead of contributing to the development of AIB, it appears that bronchovascular leakage may protect the airway mucosa from dry air-induced injury. In addition, human and animal studies reveal that airway cooling can attenuate AIB, and may do so by inhibiting either neuronal activity or mediator production and release. Finally, there is strong evidence implicating a variety of biochemical mediators in the initiation of AIB, although it is unclear at this time which mediators are a consequence of and which contribute to the development of either AIB or vascular hyperpermeability. The fact that AIB can occur in animals and normal man suggests that asthmatic subjects exhibit an enhanced version of a typical mammalian response to airway desiccation. If this is correct, then understanding the mechanisms responsible for AIB in animals and normal humans will provide important insights into its aetiology in asthmatic subjects.

Acknowledgements: The author thanks W. Ehrlich, C. Omori, B.H. Schofield, and E. M. Wagner for their critical review of an early draft of this manuscript.

\section{References}

1. Adams F. In: The extant works of Aretaeus the Cappadocian. London, Sydenham Society, 1856; pp. 1-316.

2. Floyer J. In: A treatise of the asthma. London, R. Wilkin and W. Innis, 1698.

3. Herxheimer H. Hyperventilation asthma. Lancet 1946; i: $83-87$.

4. Hellemans A, Bunch BH. In: The Timetables of Science. New York, Simon and Schuster, 1988.

5. Lee TH, Anderson SD. Heterogeneity of mechanisms in exercise-induced asthma. Thorax 1985; 40: 481487.

6. Ray DW, Hernandez C, Munoz N, Leff AR, Solway J. Bronchoconstriction elicited by isocapnic hyperpnea in guinea-pigs. J Appl Physiol 1988; 65: 934-939.

7. Chapman RW, Danko G. Hyperventilation-induced bronchconstriction in guinea-pigs. Int Arch Allergy Appl Immunol 1985; 78: 190-196.

8. Koyama S, Ohtsuka A, Horie T. Eucapnic hyperventilation-induced bronchoconstriction in rabbits. Tohoku J Exp Med 1992; 168: 611-619.

9. Freed AN, Adkinson NF Jr. Dry air-induced late phase responses in the canine lung periphery. Eur Respir $J$ 1990; 3: 434-440.

10. Freed AN, Omori C, Hubbard WC, Adkinson NF Jr. Dry air- and hypertonic aerosol-induced bronchoconstriction in the canine lung periphery. Eur Respir J 1994; 7: 1308-1316.

11. Finnerty JP, Harvey A, Holgate ST. The relative contributions of histamine and prostanoids to bronchoconstriction provoked by isocapnic hyperventilation in asthma. Eur Respir J 1992; 5: 323-330.

12. Jammes Y, Barthelemy P, Fornaris M, Grimaud C. Coldinduced bronchospasm in normal and sensitized rabbits. Respir Physiol 1986; 63: 347-360.

13. Jammes Y, Barthelemy P, Delpierre S. Respiratory effects of cold air breathing in anesthetized cats. Respir Physiol 1983; 54: 41-54.

14. Ray DW, Garland A, Hernandez C, Eappen S, Alger L, Solway J. Time-course of bronchoconstriction induced by dry gas hyperpnea in guinea-pigs. $J$ Appl Physiol 1991; 70: 504-510.

15. Nagase T, Dallaire MJ, Ludwig MS. Airway and tissue responses during hyperpnea-induced constriction in guinea-pigs. Am J Respir Crit Care Med 1994; 149: 1342-1347.

16. Fang ZX, Lai Y-L. Oxygen radicals in bronchoconstriction of guinea-pigs elicited by isocapnic hyperpnea. J Appl Physiol 1993; 74: 627-633.

17. Ohtsuka A, Koyama S, Horie T. Refractoriness of eucapnic hyperventilation-induced bronchoconstriction in rabbits. Am J Respir Crit Care Med 1994; 149: 682686. 
18. Freed AN, Wang D, Menkes HA. Dry air-induced constriction: effects of pharmacological intervention and temperature. J Appl Physiol 1987; 62: 1794-1800.

19. Freed AN, Bromberger-Barnea B, Menkes HA. Dry airinduced constriction in lung periphery: a canine model of exercise-induced asthma. J Appl Physiol 1985; 59: 1986-1990.

20. Freed AN, Peters SP, Menkes HA. Airflow-induced bronchoconstriction: role of epithelium and eicosanoid mediators. J Appl Physiol 1987; 62: 574-581.

21. Wang D, Adkinson NF Jr, Menkes HA, Freed AN. Aminophylline reduces airflow-induced constriction in the canine lung periphery. Am Rev Respir Dis 1988; 137: 31-37.

22. McFadden ER Jr, Lenner KAM, Strohl KP. Postexertional airway rewarming and thermally-induced asthma. J Clin Invest 1986; 78: 18-25.

23. Blackie SP, Hilliam C, Village R, Paré PD. The timecourse of bronchoconstriction in asthmatics during and after isocapnic hyperventilation. Am Rev Respir Dis 1990; 142: 1133-1136.

24. Smith CM, Anderson SD. A comparison between the airway response to isocapnic hyperventilation and hypertonic saline in subjects with asthma. Eur Respir $J$ 1989; 2: 36-43.

25. Boulet L-P, Turcotte H. Comparative effects of hyperosmolar saline inhalation and exercise in asthma. Iтmunol Allergy Pract 1989; 11: 23-30.

26. Manning PJ, Richared MD, Watson M, et al. Inhibition of exercise-induced bronchoconstriction by MK-571, a potent leukotriene $\mathrm{D}_{4}$-receptor antagonist. $N \mathrm{Engl} \mathrm{J} \mathrm{Med}$ 1990; 323: 1736-1739.

27. Biagini RE, Clark JC, Moorman WJ, Knecht EA. Evaluation of the onset and duration of response to cold air inhalation challenge in cynomolgus monkeys (Macaca fascicalaris). J Appl Toxicol 1991; 44: 1-6.

28. Ray DW, Eappen S, Hernandez C, et al. Distribution of airway narrowing during hyperpnea-induced bronchoconstriciton in guinea-pigs. J Appl Physiol 1990; 69: 1323-1329.

29. Ray DW, Hernandez C, Leff AR, Drazen JM, Solway J. Tachykinins mediate bronchoconstriction elicited by isocapnic hyperpnea in guinea pigs. J Appl Physiol 1989; 66: 1108-1112.

30. Anderson SD, Schoeffel RE, Follet R, Perry CP, Daviskas E, Kendall M. Sensitivity to heat and water loss at rest and during exercise in asthmatic patients. Eur J Respir Dis 1982; 63: 459-471.

31. Edmunds AT, Tooley M, Godfrey S. The refractory period after exercise-induced asthma: its duration and relation to the severity of exercise. Am Rev Respir Dis 1978; 117: 247-254

32. Aitken ML, Marini JJ. Effect of heat delivery and extraction on airway conductance in normal and in asthmatic subjects. Am Rev Respir Dis 1985; 131: 357-361.

33. Zawadski DK, Lenner KA, McFadden ER Jr. Comparison of intra-airway temperatures in normal and asthmatic subjects after hyperpnea with hot, cold, and ambient air. Am Rev Respir Dis 1989; 138: 1553-1558.

34. Farley RD, Albazzaz MK, Patel KR. Role of cooling and drying in hyperventilation induced asthma. Thorax 1988; 43: 289-294.

35. Welty C, Weiss ST, Tager IB, et al. The relationship of airways responsiveness to cold air, cigarette smoking and atopy to respiratory symptoms and pulmonary function in adults. Am Rev Respir Dis 1984; 130: 198203.
36. Amirav I, Plit M. Temperature and humidity modify airway response to inhaled histamine in normal subjects. Am Rev Respir Dis 1989; 140: 1416-1420.

37. Suzuki S, Ishii M, Sasaki J, Takishima T. Bronchial responsiveness to methacholine during airway cooling in normal subjects. Clin Allergy 1986; 16: 33-40.

38. Dosman JA, Hodgson WC, Cockcroft DW. Effect of cold air on the bronchial response to inhaled histamine in patients with asthma. Am Rev Respir Dis 1991; 144: 45-50.

39. Ahmed T, Danta I. Effect of cold air exposure and exercise on nonspecific bronchial reactivity. Chest 1988; 93: 1132-1136.

40. Schachter EN, Rimar S, Littner M, Beck GJ, Bouhuys A. Airway reactivity and exercise in healthy subjects. Chest 1982; 81: 481-485.

41. Tessier P, Cartier A, Ghezzo H, Martin RR, Malo JL. Bronchoconstriction due to exercise combined with cold air inhalation does not generally influence bronchial responsiveness to inhaled histamine in asthmatic subjects. Eur Respir J 1988; 1: 133-138.

42. Zawadski DK, Lenner KA, McFadden ER Jr. Effect of exercise on nonspecific airway reactivity in asthmatics. J Appl Physiol 1988; 64: 812-816.

43. O'Byrne PM, Jones GL. The effect of indomethacin on exercise-induced bronchoconstriction and refractoriness after exercise. Am Rev Respir Dis 1986; 134: 6972.

44. Margolskee DJ, Bigby BG, Boushey HA. Indomethacin blocks airway tolerance to repetitive exercise but not to eucapnic hyperpnea in asthmatic subjects. Am Rev Respir Dis 1988; 137: 842-846.

45. Manning PJ, Watson R, O'Byrne PM. The effects of $\mathrm{H}_{2}-$ receptor antagonists on exercise refractoriness in asthma. J Allergy Clin Immunol 1992; 90: 125-126.

46. Manning PJ, Watson RM, O'Byrne PM. Exercise-induced refractoriness in asthmatic subjects involves leukotriene and prostaglandin interdependent mechanisms. Am Rev Respir Dis 1993; 148: 950-954.

47. Rakotosihanaka F, Melaman F, D'Athis P, Florentin D, Dessanges JF, Lockhart A. Refractoriness after hyperventilation-induced asthma. Bull Eur Physiopathol Respir 1986; 22: 581-587.

48. Belcher NG, Rees PJ, Clark TJH, Lee TH. A comparison of the refractory periods induced by hypertonic airway challenge and exercise in bronchial asthma. Am Rev Respir Dis 1987; 135: 822-825.

49. Anderson SD, Schoeffel RE. Respiratory heat and water loss during exercise in patients with asthma. Eur J Respir Dis 1982; 63: 472-480.

50. Wilson NM, Barnes PJ, Vickers H, Silverman M. Hyperventilation-induced asthma: evidence for two mechanisms. Thorax 1982; 37: 657-662.

51. Pliss LB, Ingenito EP, Ingram RH, Pichurko B. Assessment of bronchoalveolar cell and mediator response to isocapnic hyperpnea in asthma. Am Rev Respir Dis 1990; 142: 73-78.

52. Ingenito EP, Pliss LB, Ingram RH, Pichurko BM. Bronchoalveolar lavage cell and mediator responses to hyperpnea-induced bronchoconstriction in the guinea-pig. Am Rev Respir Dis 1990; 141: 1162-1166.

53. Wang D, Chen HI, Chou CL, Hsu K, Freed AN. Terbutaline acts at multiple sites to inhibit bronchoconstriction induced by dry air in canine peripheral airways. Am Rev Respir Dis 1992; 145: 1295-1300.

54. Speelberg B, Verhoeff NPLG, van den Berg NJ, Oosthoek CHA, van Herwaarden CLA, Bruijnzeel PLB. Nedocromil 
sodium inhibits the early and late asthmatic response to exercise. Eur Respir J 1992; 5: 430-437.

55. Speelberg B, van den Berg NJ, Oosthoek CHA, Verhoeff NPLG, van den Brink WTJ. Immediate and late asthmatic responses induced by exercise in patients with reversible airflow limitation. Eur Respir J 1989; 2: 402-408.

56. Iikura Y, Inui H, Nagakura T, Lee TH. Factors predisposing to exercise-induced late asthmatic responses. $J$ Allergy Clin Immunol 1985; 75: 289-295.

57. Foresi A, Mattoli S, Corbo GM, Verga A, Sommaruga A, Ciappi G. Late bronchial response and increase in methacholine hyperresponsiveness after exercise and distilled water challenge in atopic subjects with asthma with dual asthmatic response to allergen inhalation. $J$ Allergy Clin Immunol 1986; 78: 1130-1139.

58. Freed AN, Yiin KT, Stream CE. Hyperosmotic-induced bronchoconstriction in the canine lung periphery. $J$ Appl Physiol 1989; 67: 2571-2578.

59. Belcher NG, Lee TH, Rees PJ. Airway responses to hypertonic saline, exercise and histamine challenges in bronchial asthma. Eur Respir J 1989; 2: 44-48.

60. Smith CM, Anderson SD. Hyperosmolarity as the stimulus to asthma induced by hyperventilation? J Allergy Clin Immunol 1986; 77: 729-736.

61. Belcher NG, Murdoch RD, Dalton N, et al. A comparison of mediator and catecholamine release between exercise- and hypertonic saline-induced asthma. Am Rev Respir Dis 1988; 137: 1026-1032.

62. Anderson SD, Schoeffel RE, Finney M. Evaluation of ultrasonically nebulised solutions for provocation testing in patients with asthma. Thorax 1983; 38: 284-291.

63. Freed AN, Omori C, Schofield BH, Mitzner W. Dry air-induced mucosal cell injury and bronchovascular leakage in canine peripheral airways. Am J Respir Cell Mol Biol 1994; 11: 724-732.

64. Omori C, Schofield BH, Mitzner W, Freed AN. Hyperpnea with dry air causes time-dependent alterations in mucosal morphology and bronchovascular permeability. J Appl Physiol 1995; 78: 1043-1051.

65. Freed AN, Omori C, Schofield BH. The effect of bronchial blood flow on hyperpnea-induced airway obstruction. $J$ Clin Invest 1995; 96: 1221-1229.

66. Crimi E, Balbo A, Milanese M, Miadonna A, Rossi GA, Brusasco V. Airway inflammation and occurrence of delayed bronchoconstriction in exercise-induced asthma. Am Rev Respir Dis 1992; 146: 507-512.

67. Garland A, Jordan JE, Ray DW, Spaethe SM, Alger L, Solway J. Role of eicosanoids in hyperpnea-induced airway responses in guinea-pigs. J Appl Physiol 1993; 75: 2797-2804.

68. Garland A, Ray DW, Doerschuk CM, Alger L, et al. Role of tachykinins in hyperpnea-induced bronchovascular hyperpermeability in guinea-pigs. $J$ Appl Physiol 1991; 70: 27-35.

69. Solway J, Kao BM, Jordan JE, et al. Tachykinin receptor antagonists inhibit hyperpnea-induced bronchoconstriction in guinea-pigs. J Clin Invest 1993; 92: 315-323.

70. Horie T, Koyama S, Omori C, et al. Peripheral airway obstruction and treatment. Nippon Kyobu Shik Gak Zas 1992; 30: 1617-1623.

71. Ohtsuka A, Koyama S, Horie T. Influence of airway temperature and humidity of hyperventilation induced bronchoconstriction in rabbits. Arerugi 1993; 42: 864-869.

72. Fuller SD, Freed AN. No influence of airway heat flux on airflow-induced bronchospasm. Eur Respir J 1992; 5: 707-711.
73. Eschenbacher WL, Moore TB, Lorenzen TJ, Weg JG, Gross KB. Pulmonary responses of asthmatic and normal subjects to different temperature and humidity conditions in an environmental chamber. Lung 1992; 170: 51-62.

74. Chen WY, Horton DJ. Heat and water loss from the airways and exercise-induced asthma. Respiration 1977; 34 : 305-313.

75. Strauss RH, McFadden ER, Ingram RH, Deal EC, Jaeger JJ. Influence of heat and humidity on the airway obstruction induced by exercise in asthma. J Clin Invest 1978; 61: 433-440.

76. Bar-Or O, Neuman I, Dotan R. Effects of dry and humid climates on exercise-induced asthma in children and preadolescents. J Allergy Clin Immunol 1977; 60: 163-168.

77. Tang G-J, Freed AN. The autonomic nervous system modulates dry air-induced constriction in the canine lung periphery. Am Rev Respir Dis 1992; 145: 13011305 .

78. Godfrey S, König P. Inhibition of exercise-induced asthma by different pharmacological pathways. Thorax 1976; 31: 137-143.

79. Thomson NC, Patel KR, Kerr JW. Sodium cromoglycate and ipratropium bromide in exercise-induced asthma. Thorax 1978; 33: 694-699.

80. Smith CM, Anderson SD, Seale JP. The duration of action of the combination of fenoterol hydrobromide and ipratropium bromide in protecting against asthma provoked by hyperpnea. Chest 1988; 94: 709-717.

81. Magnussen H, Nowak D, Wiebicke W. Effect of inhaled ipratropium bromide on the airway response to methacholine, histamine, and exercise in patients with mild bronchial asthma. Respiration 1994; 59: 42-47.

82. Finnerty JP, Holgate ST. The contribution of histamine release and vagal reflexes, alone and in combination, to exercise-induced asthma. Eur Respir J 1993; 6: 11321137.

83. Griffin MP, Fung KF, Ingram RH Jr, McFadden ER Jr. Dose-response effects of atropine on thermal stimulusresponse relationships in asthma. J Appl Physiol: Respirat Environ Exercise Physiol 1982; 53: 1576-1582.

84. Omori C, Mitzner W, Freed AN. The effects of $\alpha$-adrenergic agonists on hyperpnea-induced airway obstruction in dogs. Am J Respir Crit Care Med 1995; 152: 1723.

85. Xuan ATD, Chaussain M, Regnard J, Lockhart. Pretreatment with an inhaled $\alpha_{1}$-adrenergic agonist, methoxamine, reduces exercise-induced asthma. Eur Respir J 1989; 2: 409-414.

86. Gilbert IA, McFadden ER Jr. Airway cooling and rewarming: the second reaction sequence in exercise-induced asthma. J Clin Invest 1992; 90: 699-704.

87. Walden SM, Britt EJ, Permutt S, Bleecker ER. The effect of $\alpha$-adrenergic and antihistaminic blockade on conditioned cold air and exercise-induced asthma. Chest 1985; 87: 195S-197S.

88. Walden SM, Bleecker ER, Chahal K, Britt EJ, Mason P, Permutt S. Effect of alpha-adrenergic blockade on exercise-induced asthma and conditioned cold air. Am Rev Respir Dis 1984; 130: 357-362.

89. Barnes PJ, Wilson NM, Vickers H. Prazosin, an alpha adrenoceptor antagonist, partially inhibits exercise-induced asthma. J Allergy Clin Immunol 1981; 68: 411-415.

90. Teeter JG, Freed AN. Effect of salbutamol on dry airand acetylcholine-induced bronchoconstriction in the canine lung periphery. Eur Respir J 1991; 4: 972978. 
91. Anderson SD, Seale JP, Rozea P, Bandler L, Theobald G, Lindsay DA. Inhaled and oral salbutamol in exercise-induced asthma. Am Rev Respir Dis 1976; 114: 493-500.

92. Lindeman KS, Hirshman CA, Freed AN. Calcium channel blockers modulate airway constriction in the canine lung periphery. J Appl Physiol 1991; 70: 624-630.

93. Freed AN, Munakata M. Dry air-induced bronchoconstriction: a role for voltage-sensitive calcium channels? Am Rev Respir Dis 1989; 140: 344-349.

94. Patel KR, Peers E. Feoldipine, a new calcium antagonist, modifies exercise-induced asthma. Am Rev Respir Dis 1988; 138: 54-56.

95. Ben-Dov I, Sue DY, Hansen JE, Wasserman K. Bronchodilation and attenuation of exercise-induced bronchospasm by PY 108-068, a new calcium antagonist. $A m$ Rev Respir Dis 1986; 133: 116-119.

96. Corris PA, Nariman S, Gibson GJ. Nifedipine in the prevention of asthma induced by exercise and histamine. Am Rev Respir Dis 1983; 128: 991-992.

97. Solway J, Fanta CH. Differential inhibition of bronchoconstriction by the calcium channel blockers, verapamil and nifedipine. Am Rev Respir Dis 1985; 132: 666-670.

98. Foresi A, Corbo GM, Ciappi G, Valente S, Polidori G. Effect of two doses of inhaled diltazem on exerciseinduced asthma. Respiration 1987; 51: 241-247.

99. Ioli F, Donner CF, Fracchia C, Patessio A, Aprile C. Sustained-release anhydrous theophylline in preventing exercise-induced asthma. Respiration 1984; 46: 105113.

100. Merland N, Cartier A, L'Archeveque J, Ghezzo H, Malo J-L. Theophylline minimally inhibits bronchoconstriction induced by dry cold air inhalation in asthmatic subjects. Am Rev Respir Dis 1988; 137: 1304-1308.

101. Robuschi M, Riva E, Fuccella LM, et al. Prevention of exercise-induced bronchoconstriction by a new leukotriene antagonist (SK\&F 104353). Am Rev Respir Dis 1992; 145: 1285-1288.

102. Finnerty JP, Holgate ST. Evidence for the roles of histamine and prostaglandins as mediators in exercise-induced asthma: the inhibitory effect of terfenadine and flurbiprofen alone and in combination. Eur Respir J 1990; 3: $540-547$.

103. Magnussen H, Boerger S, Templin K, Baunack AR. Effects of a thromboxane-receptor antagonist, BAYu3405, on prostaglandin $\mathrm{D}_{2}$ - and exercise-induced bronchoconstriction. J Allergy Clin Immunol 1992; 89: 11191126.

104. Finnerty JP, Twentyman OP, Harris A, Palmer JBD, Holgate ST. Effect of GR32191, a potent thromboxane receptor antagonist, on exercise-induced bronchoconstriction in asthma. Thorax 1991; 46: 190-192.

105. Israel E, Callaghan JT, Mathur PN, et al. Effect of a leukotriene antagonist, LY171883, on cold air-induced bronchoconstriction in asthmatics. Am Rev Respir Dis 1990; 140: 1348-1353.

106. Finnerty JP, Wood-Baker R, Thomson H, Holgate ST. Role of leukotrienes in exercise-induced asthma. $A m$ Rev Respir Dis 1992; 145: 746-749.

107. Omori C, Freed AN. Leukotrienes modulate airflowinduced bronchoconstriction in canine periperal airways. Am Rev Respir Dis 1993; 147: A296.

108. Israel E, Dermarkarian R, Rosenberg M, et al. The effects of a 5-lipoxygenase inhibitor on asthma induced by cold, dry air. N Engl J Med 1990; 323: 1740-1744.

109. Pavord ID, Wisniewski A, Tattersfield AE. Inhaled frusemide and exercise-induced asthma: evidence of a role for inhibitory prostanoids. Thorax 1992; 47: 797800.

110. Gilbert IA, Lenner KA, Nelson JA, Wolin AD, Fouke JM. Inhaled furosemide attenuates hyperpnea-induced obstruction and intra-airway thermal gradients. J Appl Physiol 1994; 76: 409-415.

111. Bianco S, Robusch M, Vaghi A, Pasargiklian M. Prevention of exercise-induced bronchoconstriction by inhlaed frusemide. Lancet 1988; 2: 252-255.

112. Rodwell LT, Anderson SD, Du Toit J, Seale JP. Different effects of inhaled amiloride and frusemide on airway responsiveness to dry air challenge in asthmatic subjects. Eur Respir J 1993; 6: 855-861.

113. Freed AN, Kelly LJ, Menkes HA. Airflow-induced bronchospasm: imbalance between airway cooling and airway drying. Am Rev Respir Dis 1987; 136: 595-599.

114. Freed AN, Fuller SD, Stream CE. Transient airway cooling modulates dry air-induced and hypertonic aerosolinduced bronchoconstriction. Am Rev Respir Dis 1991; 144: 358-362.

115. Freed AN, Stream CE. Airway cooling: stimulus specific modulation of airway responsiveness in the canine lung periphery. Eur Respir J 1991; 4: 568-574.

116. Mihalyka M, Wong J, James AL, Anderson SD, Paré PD. The effect on airway function of inspired air conditions after isocapnic hyperventilation with dry air. Clin Immunol 1988; 82: 842-848.

117. Gilbert IA, Fouke JM, McFadden ER Jr. Intra-airway thermodynamics during exercise and hyperventilation in asthmatics. J Appl Physiol 1988; 64: 2167-2174.

118. O'Cain CF, Dowling NB, Slutsky AS, et al. Airway effects of respiratory heat loss in normal subjects. J Appl Physiol 1980; 49: 875-880.

119. Deal EC Jr, McFadden ER, Ingram RH, Breslin FJ, Jaeger JJ. Airway responsiveness to cold air and hyperpnea in normal subjects and in those with hayfever and asthma. Am Rev Respir Dis 1980; 121: 621-638.

120. Quaedvlieg M, Wouters EF. Early airway obstruction in young asymptomatic smokers after cold air challenge. Respiration 1990; 57: 299-303.

121. Mitzner W. Collateral ventilation. In: Crystal RG, West JB, eds. The Lung: Scientific Foundations New York, Raven Press, Ltd, 1991; pp. 1053-1063.

122. Baker MA, Hawkins MJ, Rader RD. Thermoregulatory influences on common carotid blood flow in the dog. $J$ Appl Physiol:Respirat Environ Exercise Physiol 1982; 52: $1138-1146$

123. Daviskas E, Gonda I, Anderson SD. Local airway heat and water vapour losses. Respir Physiol 1991; 84: 115-132.

124. Solway J, Pichurko BM, Ingenito EP, et al. Breathing pattern affects airway wall temperature during cold air hyperpnea in humans. Am Rev Respir Dis 1985; 132: 853-857.

125. Ray DW, Ingenito EP, Strek M, Schumacker PT, Solway J. Longitudinal distribution of canine respiratory heat and water exchanges. J Appl Physiol 1989; 66: 27882798.

126. McFadden ER Jr, Pichurko BM, Bowman HF, et al. Thermal mapping of the airways in humans. J Appl Physiol 1985; 58: 564-570.

127. Beck KC, Offord KP, Scanlon PD. Bronchoconstriction occurring during exercise in asthmatic subjects. $\mathrm{Am}$ J Respir Crit Care Med 1994; 149: 352-357.

128. Mussaffi H, Springer C, Godfrey S. Increased bronchial responsiveness to exercise and histamine after allergen 
challenge in children with asthma. J Allergy Clin Immunol 1986; 77: 48-52.

129. Ben-Dov I, Bar-Yishay E, Godfrey S. Refractory period after exercise-induced asthma unexplained by respiratoy heat loss. Am Rev Respir Dis 1982; 125: 530-534.

130. Broide DH, Eisman S, Ramsdell JW, Ferguson P, Schwartz LB, Wasserman SI. Airway levels of mast cell-derived mediators in exercise-induced asthma. Am Rev Respir Dis 1990; 141: 563-568.

131. Jarjour NN, Calhoun WJ. Exercise-induced asthma is not associated with mast cell activation or airway inflammation. J Allergy Clin Immunol 1992; 89: 6068 .

132. Rubinstein I, Levinson H, Slutsky AS, et al. Immediate and delayed bronchconstriction after exercise in patients with asthma. N Engl J Med 1987; 317: 483-485.

133. Zawadski DK, Lenner KA, McFadden ER Jr. Re-examination of the late asthmatic response to exercise. $\mathrm{Am}$ Rev Respir Dis 1988; 137: 837-841.

134. Lee TH, Nagakura T, Papageorgiou N, Iikura Y, Kay AB. Exercise-induced late asthmatic reactions with neutrophil chemotactic activity. N Engl J Med 1983; 308: 1502-1505.

135. Bierman CW, Spiro SG, Petheram I. Characterization of the late response in exercise-induced asthma. J Allergy Clin Immunol 1984; 74: 701-706.

136. Neijiens HJ, Gargani G, Van Kralingen A, Weezepoel $\mathrm{V}$, Kerrebijn KF. Central versus peripheral airways obstruction in bronchial responsiveness due to exercise. Eur J Respir Dis 1982; 121: 105-112.

137. Wesseling GJ, Wouters EF. Respiratory impedance measurements in a dose-response study of isocapnic hyperventilation with cold air. Respiration 1992; 59: 259264.

138. Davis B, Marin MG, Yee JW, Nadel JA. Effect of terbutaline on movement of $\mathrm{Cl}^{-}$and $\mathrm{Na}^{+}$across the trachea of the dog in vitro. Am Rev Respir Dis 1979; 120: 547552.

139. McFadden ER, Kiser R, DeGroot WJ. Acute bronchial asthma: relations between clinical and physiologic manifestations. N Engl J Med 1973; 288: 221-225.

140. Popa V, Rients P. The effect of inhaled naloxone on resting bronchial tone and exercise-induced asthma. Am Rev Respir Dis 1989; 139: 702-709.

141. Wilkens JH, Wilkens H, Uffmann J, Bover J, Fabel J, Frolich J. Effects of PAF-antagonist (BN 52063) on bronchoconstriction and platelet activation during exercise-induced asthma. Br J Clin Pharmacol 1990; 29: 85-91.

142. Wiebicke W, Jorres R, Magnussen H. Comparison of the effects of inhaled corticosteroids on the airway response to histamine, methacholine, hyperventilation, and sulfur dioxide in subjects with asthma. J Allergy Clin Immunol 1990; 86: 915-923.

143. Lung MAKY, Wang JCC, Cheng KK. Bronchial circulation: an auto-perfusion method for assessing its vasomotor activity and the study of $\alpha$ - and $\beta$-adrenoceptors in the bronchial artery. Life Sci 1976; 19: 577-580.

144. Cox JSG, Altounyan REC. Nature and action of disodium cromoglycate (Lomidal). Respiration 1970; 27: 292-309.

145. Fuller RW, Collier J. Sodium cromoglycate and atropine block the fall in FEV1, but not the cough induced by hypotonic mist. Thorax 1984; 39: 766-770.

146. Finnerty JP, Wilmot C, Holgate ST. Inhibition of hypertonic saline-induced bronchoconstricton by terfenadine and flurbiprofen. Am Rev Respir Dis 1989; 140: 593-597.
147. O'Byrne PM, Thomson NC, Morris M, Roberts RS, Daniel EE, Hargreave FE. The protective effect of inhaled chlorpheniramine and atropine on bronchoconstriction stimulated by airway cooling. Am Rev Respir Dis 1983; 128: 611-617.

148. Ventresca PG, Nichol GM, Barnes PJ, Chung KF. Inhaled furosemide inhibits cough induced by low chloride content solutions but not by capsaicin. Am Rev Respir Dis 1990; 142: 143-146.

149. Moscato G, Dellabianca A, Falagiani P, Mistrello G, Rossi G, Rampulla C. Inhaled furosemide prevents both the bronchoconstriction and the increase in neutrophil chemotactic activity induced by ultrasonic "fog" of distilled water in asthmatics. Am Rev Respir Dis 1991; 143: 561-566.

150. Martling CR. Sensory nerves containing tachykinin and CGRP in the lower airways: functional implications for bronchoconstriction, vasodilation and protein extravasation. Acta Physiol Scand 1987; 563: S1-S57.

151. Goldie RG. Receptors in asthmatic airways. Am Rev Respir Dis 1990; 141: S151-S156.

152. Lundberg JM, Martling C-R, Saria A. Substance P and capsaicin-induced contraction of human bronchi. Acta Physiol Scand 1983; 119: 49-53.

153. Eggleston PA, Kagey-Sobotka A, Lichtenstein LM. A comparison of the osmotic activation of basophils and human lung mast cells. Am Rev Respir Dis 1987; 135: 1043-1048.

154. Silber $\mathrm{G}$, Proud $\mathrm{D}$, Warner $\mathrm{J}$, et al. In vivo release of inflammatory mediators by hyperosmolar solutions. Am Rev Respir Dis 1988; 137: 606-612.

155. Makker HK, Walls AF, Goulding D, et al. Airway effects of local challenge with hypertonic saline in exercisedinduced asthma. Am J Respir Crit Care Med 1994; 149: 1012-1019.

156. Smith CM, Anderson SD, Walsh S, McElrea MS. An investigation of the effects of heat and water exchange in the recovery period after exercise in children with asthma. Am Rev Respir Dis 1989; 140: 598-605.

157. Baile EM, Dahlby RW, Wiggs BR, Parsons GH, Paré PD. Effect of cold and warm dry air hyperventilation on canine airway blood flow. J Appl Physiol 1987; 62: 526-532.

158. Baile EM, Godden DJ, Paré PD. Mechanism for increase in tracheobronchial blood flow induced by hyperventilation of dry air in dogs. J Appl Physiol 1990; 68: 105-112.

159. Parsons GH, Paré PD, White DA, Baile EM. Airway blood flow response to eucapnic dry air hyperventilation in sheep. J Appl Physiol 1989; 66: 1443-1447.

160. Kelly L, Kolbe J, Mitzner W, Spannhake EW, BrombergerBarnea B, Menkes H. Bronchial blood flow affects recovery from constriction in dog lung periphery. $J$ Appl Physiol 1986; 60: 1954-1959.

161. Wagner EM, Mitzner WA. Bronchial circulatory reversal of methacholine-induced airway constriction. J Appl Physiol 1990; 69: 1220-1224.

162. Bundgaard A, Enehjelm SD, Aggestrup S. Pretreatment of exercise-induced asthma with inhaled vasoactive intestinal peptide (VIP). Eur J Respir Dis 1983; 64 (S128): 427-429.

163. Barnes PJ, Dixon CMS. The effect of inhaled vasoactive intestinal peptide on bronchial reactivity to histamine in humans. Am Rev Respir Dis 1984; 130: 162-166.

164. Tam EK, Caughey GH. Degradation of airway neuropeptides by human lung tryptase. Am J Respir Cell Mol Biol 1990; 3: 27-32. 
165. Uchida Y, Ninomiya H, Saotome M, et al. Endothelin, a novel vasoconstrictor peptide, as potent bronchoconstrictor. Eur J Pharmacol 1988; 154: 227-228.

166. Bédard M, McClure CD, Schiller NL, Francoeur C, Cantin A, Denis M. Release of interleukin-8, interleukin-6, and colony-stimulating factors by upper airway epithelial cells: implications for cystic fibrosis. Am J Respir Cell Mol Biol 1993; 9: 455-462.

167. Marini M, Vittori E, Hollemborg J, Mattoli S. Expression of the potent inflammatory cytokines, granulocyte/ macrophage colony-stimulating factor and interleukin-6 and interleukin-8, in bronchial epithelial cells of patients with asthma. J Allergy Clin Immunol 1992; 89: 1001-1009.

168. LeMay DR, LeMay LG, Kluger MJ, D'Alecy LG. Plasma profiles of IL-6 and TNF with fever-inducing doses of lipopolysaccharide in dogs. Am J Physiol 1990; 259: R126-R132.

169. Dupuy PM, Shore SA, Drazen JM, Frostell C, Hill WA, Zapol WM. Bronchodilator action of inhaled nitric oxide in guinea-pigs. J Clin Invest 1992; 90: 421-428.

170. Högman M, Frostell CG, Hedenstrom H, Hedenstierna G. Inhalation of nitric oxide modulates adult human bronchial tone. Am Rev Respir Dis 1993; 148: 1474 1478.

171. Nijkamp FP, Van Der Linde HJ, Folkerts G. Nitric oxide synthesis inhibitors induce airway hyperresponsiveness in the guinea-pig in vivo and in vitro: role of the epithelium. Am Rev Respir Dis 1993; 148: 727-734.

172. Godden DJ, Baile EM, Okazawa M, Paré PD. Hypertonic aerosol inhalation does not alter central airway blood flow in dogs. J Appl Physiol 1988; 65: 1990-1994.
173. Blosser S, Mitzner W, Wagner EM. Effects of increased bronchial blood flow on airway morphometry, resistance and reactivity. J Appl Physiol 1994; 76: 1624-1629.

174. Gilbert IA, Regnard J, Lenner KA, Nelson JA, McFadden ER Jr. Intrathoracic airstream temperatures during acute expansions of thoracic blood volume. Clin Sci 1991; 81: 655-661.

175. Gilbert IA, Winslow CJ, Lenner KA, Nelson JA, McFadden JR Jr. Vascular volume expansion and thermally-induced asthma. Eur Respir J 1993; 6: 189-197.

176. Tang G-J, Freed AN. The role of submucosal oedema in increased peripheral airway resistance by intravenous volume loading in dogs. Eur Respir J 1994; 7: 311-317.

177. Paré PD Godden DJ. Airway Edema. In: Crystal RG, West JB, eds, The Lung: Scientific Foundations. New York, Raven Press Ltd, 1991; pp. 987-994.

178. Deffebach ME, Charan NB, Lakshminarayan S, Butler J. The bronchial circulation: small, but a vital attribute of the lung. Am Rev Respir Dis 1987; 135: 463-481.

179. Omori C, Schofield BH, Mitzner W, Freed AN. A $\beta_{2^{-}}$ adrenergic agonist inhibits dry air-induced injury in canine peripheral airways. J Appl Physiol 1995; 78: 2169-2179.

180. Persson CG, Erjefalt I, Alkner U, et al. Plasma exudation as a first line respiratory mucosal defence. Clin Exp Allergy 1991; 21: 17-24.

181. Gilbert IA, Fouke JM, McFadden ER Jr. Heat and water flux in the intrathoracic airways and exercise-induced asthma. J Appl Physiol 1987; 63: 1681-1691.

182. Rydstrom PO, Ulriksen H. High prevalence of asthma in cross country skiers. Br Med J 1993; 307: 1326-1329.

183. Carlsen KH. Bronchial hyperreactivity in athletes Nord Med 1994; 109: 16-18. 